\title{
Unusual late presentation of coarctation of aorta with right subclavian artery aneurysm
}

\author{
Vineeta Ojha (1), Sreenivasa Narayana Raju, Kartik P Ganga (1) , Arun Sharma
}

Department of Cardiovascular Radiology and Endovascular Interventions, All India Institute of Medical Sciences, New Delhi, Delhi, India

\section{Correspondence to}

Dr Arun Sharma;

drarungautam@gmail.com

Accepted 15 January 2020

\section{DESCRIPTION}

Echocardiography in a 64-year-old patient with dyspnoea revealed coarctation of aorta with an aneurysm in the region of ascending aorta. CT angiography (CTA) showed juxtaductal coarctation of aorta (figure 1A,B). Additionally, a large saccular peripherally calcified aneurysm (figure $1 \mathrm{~A}, \mathrm{C}$ ) was seen arising from first part of right subclavian artery (RSCA) (figure 1C), which was causing significant compression of the trachea (figure 1A,D). Distal RSCA was patent but attenuated (figure 1C). The right internal mammary artery was attenuated compared with left (figure 1A).

True aneurysm of RSCA has been very rarely described in association with coarctation of aorta. ${ }^{1}$ Turbulent flow causing shear stress on the wall of left subclavian artery (SCA) is a mechanism well known to cause left SCA aneurysms in coarctation.

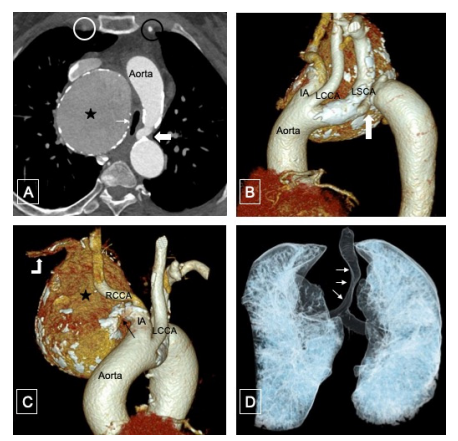

Figure $1 \mathrm{CT}$ angiography multiplanar reconstructed axial $(A)$ and volume rendered image $(B)$ reveal juxtaductal coarctation of aorta (block arrow). A large peripherally calcified aneurysm (black star in A and C) is also seen which is arising from the first part of right subclavian artery (RSCA) (black arrow in C). The aneurysm is causing significant compression of the trachea (white arrows in A and D). Distal RSCA was patent (bent arrow in C). The right internal mammary artery was attenuated (white circle in A) compared with left (black circle in A). IA, innominate artery; RCCA, right common carotid artery; LCCA, left common carotid artery; LSCA, left subclavian artery.

\section{Learning points}

- Aneurysm of right subclavian artery in the setting of coarctation of aorta is rare.

- It can impede collateralisation from first part of the right subclavian artery and hence, may be hemodynamically significant.

- CTA helps in demonstration of such vascular pathologies and more importantly, associated airway compression.

However, the mechanism of RSCA aneurysm is still debated. Recent literature suggests genetic defects in the vessel wall causing the aneurysm formation. This is haemodynamically significant as the aneurysm will impede the collateralisation from the first part of SCA as seen in our patient (attenuated right internal mammary artery). Additionally, it was also causing significant airway compression in our patient. We describe here a very unusual late presentation of coarctation with RSCA aneurysm. This case is also an excellent example of the utility of $3 \mathrm{D}$ reconstruction of the CTA images (figure $1 \mathrm{~B}-\mathrm{D}$ ) for demonstration of such vascular pathologies and also in demonstrating the airway compressions.

Contributors VO, SNR, KPG and AS contributed in planning, designing, editing and finalising the manuscript.

Funding The authors have not declared a specific grant for this research from any funding agency in the public, commercial or not-for-profit sectors.

Competing interests None declared.

Patient consent for publication Obtained.

Provenance and peer review Not commissioned; externally peer reviewed.

ORCID iDs

Vineeta Ojha http://orcid.org/0000-0003-4371-5615

Kartik P Ganga http://orcid.org/0000-0002-5391-8531

\section{REFERENCE}

1 Liu X, Li Z, He Y, et al. Right subclavian artery aneurysm: a rare complication of coarctation of the aorta. Tex Heart Inst J 2012;39:290-1. 
Copyright 2020 BMJ Publishing Group. All rights reserved. For permission to reuse any of this content visit https://www.bmj.com/company/products-services/rights-and-licensing/permissions/

BMJ Case Report Fellows may re-use this article for personal use and teaching without any further permission.

Become a Fellow of BMJ Case Reports today and you can:

- Submit as many cases as you like

Enjoy fast sympathetic peer review and rapid publication of accepted articles

Access all the published articles

Re-use any of the published material for personal use and teaching without further permission

Customer Service

If you have any further queries about your subscription, please contact our customer services team on +44 (0) 2071111105 or via email at support@bmj.com.

Visit casereports.bmj.com for more articles like this and to become a Fellow 